\title{
Sacroiliac Joint Dysfunction
}

\section{Sakroiliak Eklem Disfonksiyonu}

\begin{abstract}
AIM: Sacroiliac joint dysfunction is a disorder presenting with low back and groin pain. It should be taken into consideration during the preoperative differential diagnosis of lumbar disc herniation, lumbar spinal stenosis and facet syndrome.

MATERIAL and METHODS: Four cases with sacroiliac dysfunction are presented. The clinical and radiological signs supported the evidence of sacroiliac dysfunction, and exact diagnosis was made after positive response to sacroiliac joint block.
\end{abstract}

RESULTS: A percutaneous sacroiliac fixation provided pain relief in all cases. The mean VAS scores reduced from 8.2 to 2.2 .

CONCLUSION: It is concluded that sacroiliac joint dysfunction diagnosis requires a carefull physical examination of the sacroiliac joints in all cases with low back and groin pain. The diagnosis is made based on positive response to the sacroiliac block. Sacroiliac fixation was found to be effective in carefully selected cases.

KEYWORDS: Sacroiliac block, Sacroiliac fixation, Sacroiliac joint, Sacroiliac joint dysfunction

\section{ÖZ}

AMAÇ: Sakroiliak eklem disfonksiyonu kendini bel ve kalça ağrısı ile gösteren bir hastalıktır. Bu durum klinik olarak lomber disk hernisi, spinal stenoz ve faset sendromu ile kolayca karışabilmektedir.

YÖNTEM ve GEREÇ: Dört sakroiliak eklem disfonksiyon olgusu sunulmaktadır. Olguların klinik ve radyolojik bulgularına dayanarak sakroiliak eklem disfonksiyon ön tanısı konmuş, sakroiliak blokaja pozitif yanıtın alınması ile tanı kesinleştirilmiştir.

BULGULAR: Olguların tamamında perkütan sakroiliak fiksasyon ile ağrılar geçmiş, ortalama VAS skorları 8.2' den 2.2'e düşmüştür.

SONUÇ: Sakroiliak eklem disfonksiyonu tanısı, bel ve kalça ağrısı olan tüm olgularda bu eklemin dikkatli bir şekilde muayenesi ve radyolojik incelemesini gerektirmektedir. Sakroiliak blokaja pozitif yanıt tanıyı kesinleştirir. Sakroiliak fiksasyon dikkatle seçilmiş olgularda oldukça etkin iyileşme sağlar.

ANAHTAR SÖZCÜKLER: Sakroiliak blokaj, Sakroiliak eklem, Sakroiliak eklem disfonksiyonu, Sakroiliak fiksasyon

\section{Hakan ILASLAN ${ }^{1}$ \\ Ahmet ARSLAN ${ }^{2}$ \\ Omer Nadir KOC̣ \\ Turker DALKILIC̣ \\ Sait NADERI ${ }^{5}$
1,2,3,4 Istanbul Medipol Hospital, Department of Neurosurgery, İstanbul, Turkey
5 Ümraniye Training and Research Hospital, Department of Neurosurgery, İstanbul, Turkey

Received : 28.01.2010

Accepted : 02.02.2010

Correspondence address:

Sait NADERI

Department of Neurosurgery,

Ümraniye Training and Research Hospital,

Istanbul, TURKEY

E-mail: saitnaderi@yahoo.com 


\section{INTRODUCTION}

Sacroiliac joint dysfunction (SIJD) is one of the causes of non-discogenic pain in cases with low back and groin pain. This condition can easily be confused with conditions such as lumbar disc herniation, lumbar spinal stenosis and facet joint syndrome, which have a similar pain pattern (8). In this study, we reviewed the clinical aspect, diagnosis, and treatment methods of SIJD, in the light of cases that were diagnosed and treated as SIJD.

\section{MATERIAL and METHODS}

The charts of four patients with SIJD were reviewed. There were two males and two females. The mean age was 48.5 , ranging from 38 to 58 . All cases were admitted with low back and groin pain lasting for 3 to 10 months. Neurological examination was normal in all cases. The diagnosis was made based on the clinical and radiological findings, as well as the positive response to the sacroiliac joint block.

The pain pattern was evaluated clinically. Tenderness to the sacroiliac joint palpation and percution, and positive response to sacroiliac tests (i.e., FABERE and Gaenslen) were evaluated in favor of SIJD. The sacroiliac joint was evaluated radiologically using $\mathrm{CT}$ and MRI to determine the existence of degeneration in the sacroiliac joint, osteophytes and sclerosis. In cases suspected of having SIJD, the diagnosis was supported by a

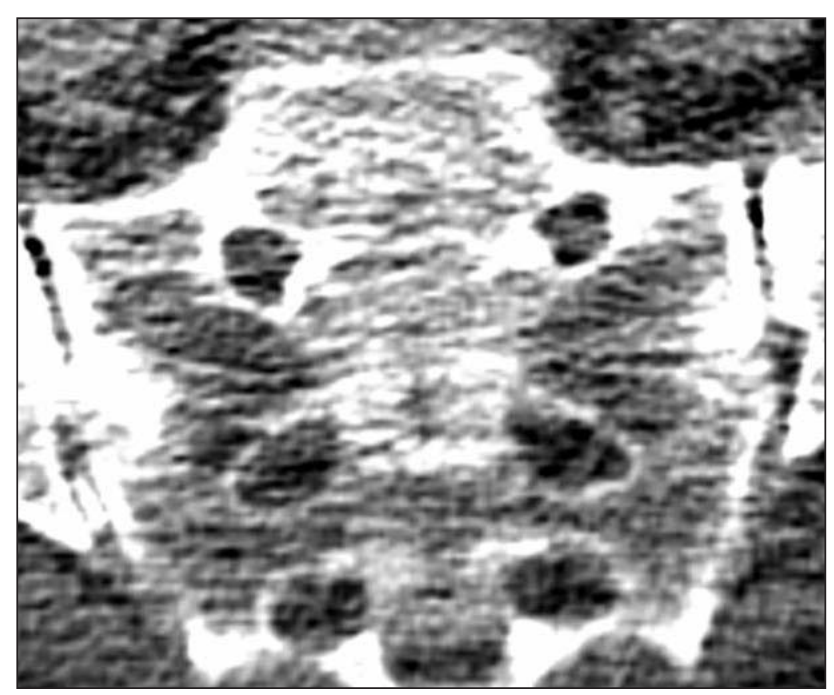

Figure 1: Preoperative sacroiliac joint CT shows the presence of the osteophyte within the sacroiliac joint. positive response to the sacroiliac joint block. A sacroiliac joint fixation was performed as the final treatment in cases that showed a temporary positive response to the sacroiliac joint block.

Surgical Technique: The patient was operated under scopic control in the prone position. A $1 \mathrm{~cm}$ incision was performed $10-14 \mathrm{~cm}$ lateral to the midline at the level of sacral pedicle under lateral scopic control. A K-wire was inserted toward the sacroiliac joint $\left(20-30^{\circ}\right.$ caudally, and $70^{\circ}$ medially) aiming to pass the SIJ. After AP and lateral scopic control of position of the $\mathrm{K}$-wire, the K-wire projectory was tapped using a cannulated tap. At the final step, a 5-7 cm x $4 \mathrm{~mm}$ cannulated screw was placed and the K-wire was removed.

\section{RESULTS}

Sacroiliac tests were positive in all cases. Both CT and MRI examination were performed in all cases. Whereas MRI showed no pathology, CT examination demonstrated osteopyhte in sacroiliac joint in one case, and sclerotic alterations in other two cases.

All cases benefited from sacroiliac block. All four cases underwent percutaneous sacroiliac joint fixation because of recurrent pain after a painless period of 10 to 14 days. Clinical conditions improved in all cases and VAS scores declined from 8.2 to 2.2. The follow-up durations ranged between 5 to 14 months (Table I).

Case 1: A 52-year-old female patient was admitted with right groin and thigh pain, lasting for 10 months. There was no neurological deficits. FABERE and Geanslen tests were positive on the right side. The right sacroiliac joint was sensitive to palpation and percussion. Sacroiliac MRI was normal. Sacroiliac CT revealed stenosis and osteophytes in the joint (Figure 1). The patient benefited from the right sacroiliac joint block. However, her pain recurred after two weeks, and she underwent a percutaneous sacroiliac joint fixation using a cannulated screw system (Figures 2, 3). The VAS score reduced from 7 to 1 .

\section{DISCUSSION}

This study revealed the efficacy of the sacroiliac block in the diagnosis of the cases with SIJD. The first step in the diagnosis of SIJD includes the use of sacroiliac tests during the preoperative examination of each patient with sciatica. A sacroiliac block is 


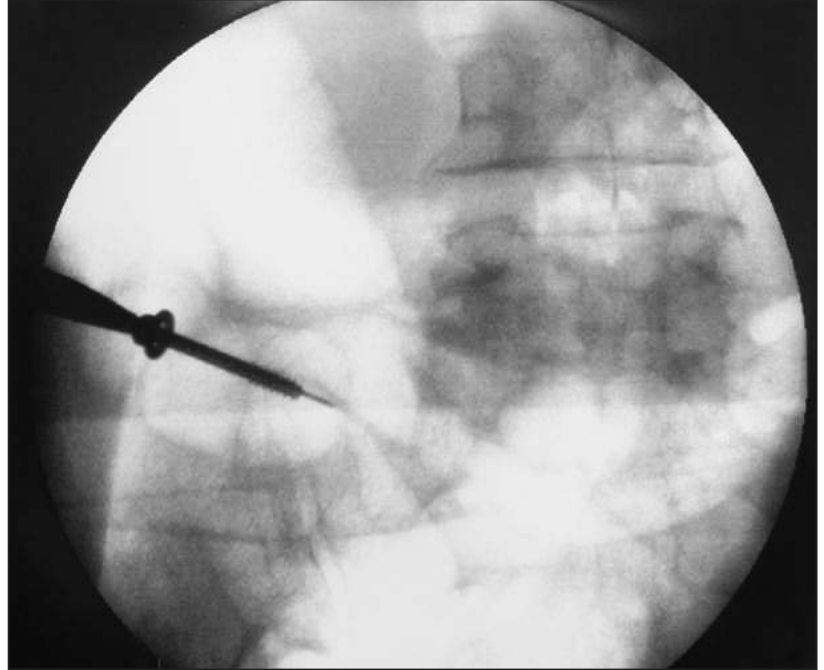

Figure 2: Percutaneous placement of the cannulated screw.

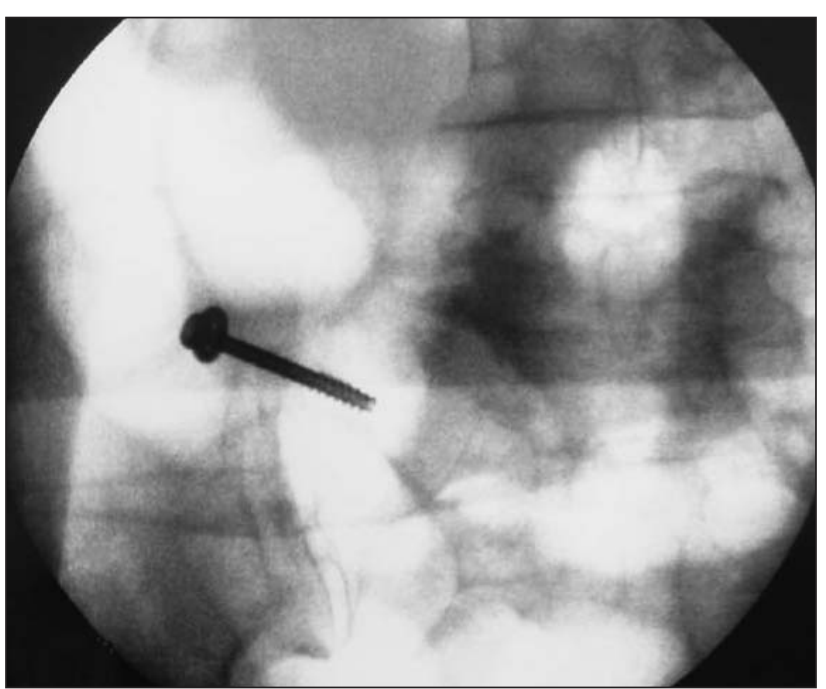

Figure 3: Postoperative appearance of the sacroiliac screw.

Table I: Preoperative and Postoperative Neurological Status (NE) and VAS Scores of Four Operated Cases

\begin{tabular}{|c|c|c|c|c|}
\hline Case \# & Preoperative NE & Postoperative NE & Preoperative VAS & Postoperative VAS \\
\hline 1 & N & N & 7 & 1 \\
\hline 2 & N & N & 9 & 3 \\
\hline 3 & N & N & 8 & 3 \\
\hline 4 & N & N & 9 & 2 \\
\hline
\end{tabular}

then performed in cases suspected of having SIJD. Temporary pain relief after the sacroiliac block proves that the sacroiliac joint is generator of the pain.

The sacroiliac joint (SIJ) can be source of pain in cases with sacroiliitis and sacroiliac dysfunction $(3,15)$. SIJ is located between the sacrum and the innominate bones, which consist of the ipsilateral ileum, ischium and pubis bones. It lies between S1 and S3. The sacrum is wedge-shaped (cuneiform) from front to back and therefore provides resistance in both vertical and horizontal shears (4). SIJ is a diarthrodial joint that contains synovial liquid $(5,7,15)$. The joint surfaces are different than the other joints in the body. Hyaline cartilage is available on the sacral surface and this surface is flat. The iliac surface is covered with a rough fibrocartilage (16).

Strong ligamentous structures and muscles support the SIJ. Ligamentous structures are effective in creating resistance to shear. Ligamentous degeneration, weakness, or recurrent exposure to trauma are the major causes of SIJD $(5,13,14)$.
According to the International Pain Studies Association, the sacroiliac joint is responsible for chronic hip pain and leg pain in $10 \%$ to $27 \%$ of cases. In this sense, the character of pain should be evaluated carefully. Sacroiliac pain is commonly sharp in character, spreading to the groin, buttocks and thighs. The pain is commonly unilateral, and increases with sitting $(3,12)$. Like discogenic sciatica, sacroiliac pain may decrease or increase. However, there is no accompanying motor, reflex and sensory deficit. The straight leg raise test is usually negative. Sacroiliac tests are helpful for the diagnosis. Accordingly, the addition of sacroiliac joint examination to the standard examination for sciatica is mandatory. The main sacroiliac provocation tests include the compression test, distraction test, FABERE test, and Gaenslen's test $(2,6,7,9,16)$.

Radiological diagnosis of SIJD is difficult (16). Sacroiliac joint CT may demonstrate osteophytes, sclerosis and degeneration. However, MRI and CT may be completely normal.

The exact diagnosis of the SIJD can be made using a sacroiliac joint block (15). The local anesthetic agent 
relieves pain and the addition of steroids reduces the local inflammation.

McKenzie-Brown et al. showed the validity of the sacroiliac block as a diagnostic test $(5,7,11)$. Maigne et al., reported the false negative rate for sacroiliac block to be $20 \%$ in 54 patients, which may be due to a technical error (10).

Sacroiliac fixation is recommended to chronic pain patients who have benefited temporarily from a sacroiliac block. Effectiveness of fixation with screws has been indicated by many studies. A study by Nelson et al. evaluated eight patients who underwent sacroiliac fixation. They reported total pain relief in all patients at the end of 5-9 months (12). On the other hand, Amoretti et al., reported sacroiliac degeneration in one $(5 \%)$ out of 20 cases who underwent sacroiliac fixation. At the end of the 3 -year follow up, they reported $95 \%$ pain relief (1). In the current study, steroid as well as local anesthetics were applied to all of the presented cases. All cases responded well to the given medicines for a 10- to 14-day period. In our cases, sacroiliac fixation has also relieved the pain quite effectively.

\section{CONCLUSION}

Sacroiliac dysfunction is one of the important causes of low back and hip pain. Diagnosis is performed based on clinical signs and physical examination findings. The definite diagnosis should be based on the positive response to the sacroiliac joint block. In cases who show temporary benefit from the sacroiliac joint block, a fixation procedure can relieve the pains of sacroiliac origin. Understanding SIJD may decrease the likelihood of unnecessary lumbosacral surgery.

\section{REFERENCES}

1. Amoretti N, Hovorka I, Marcy PY: Computed axial tomography guided fixation of sacroiliac joint disruption: Safety, outcomes and result at 3 year follow-up. Cardiovasc Intervent Radiol (online print), 2009 Jun 25

2. Cattley P, Winyard J, Trevaskis J: Validity and reliability of clinical tests for the sacroiliac joint. A review of literature: Australasian Chiropractic\&Osteopathy 10:73-80, 2002

3. Cibulka MT: The treatment of the sacroiliac joint component to low back pain: A case report. Physical Therapy 72: 917-922, 1992

4. Duyur B, Genç H: Sakroiliak eklem anatomi ve biyomekaniği. Fiziksel Tip 5: 51-55, 2002

5. Forst SL, Wheeler MT, Fortin JD: The sacroiliac joint: Anatomy, physiology and clinical significance. Pain Physician 9: 61-68, 2006

6. Fryer G, Morse CM, Johnson JC: Spinal and sacroiliac assessment and treatment techniques used by osteopathic physician in the United States. Osteopathic Medicine and Primary Care 3:4, 2009

7. Hansen HC, McKenzie-Brown AM: Sacroiliac joint interventions: A systematic review. Pain Physician 10: 165-184, 2007

8. Kulcu DG, Naderi S: Differential diagnosis of intraspinal and extraspinal non-discogenic sciatica. J Clin Neurosci 15: 12461252,2008

9. Laslett M: Evidence-based diagnosis and treatment of the painful sacroiliac joint. The Journal of Manual\&Manipulative Therapy 16: 142-152, 2008

10. Maigne JY, Aivakiklis A, Pfefer F: Results of sacroiliac joint double block and value of sacroiliac pain provacation test in 54 patients with low back pain. Spine 21: 1889-1892, 1996

11. McKenzie-Brown AM, Shah RV, Sehgal N: A systematic review of sacroiliac joint interventions. Pain Physician 8: 115126, 2005

12. Nelson DW, Duwelius PJ: CT guided fixation of sacral fractures and sacroiliac joint disruptions. Radiology 180: 52732, 1991

13. Pell JJM, Spoor CW, Pool-Goudzwaard AL: Biomechanical analysis of reducing sacroiliac joint shear load by optimization of pelvic muscle and ligament forces. Annals of Biomedical Engineering 36: 415-424, 2008

14. Pool-Goudzwaard AL, Kleinrensink GJ, Snijders CJ: The sacroiliac part of the iliolumbar ligament. Journal of Anatomy 199: 457-463, 2001

15. Rupert MP, Lee M, Manchikanti L: Evaluation of sacroiliac joint interventions: A systematic appraisal of the literature. Pain Physician 12: 399-418, 2009

16. Yıldız EÖ, Dinçer N: Sakroiliyak eklem disfonksiyonunun değerlendirilmesi ve tedavisi-derleme. Türkiye Fiziksel Tıp ve Rehabilitasyon Dergisi 50: 1, 2004 